\title{
The Transformation of the Urban Block in the City of Tirana from 1920 to 1960
}

\author{
Parashqevi Tashi ${ }^{1}$, Kejt Dhrami ${ }^{2}$, Ani Tola ${ }^{3}$ \\ ${ }^{1} \mathrm{PhD}$ Candidate, Faculty of Architecture and Urban Desing, Rruga “Muhamet Gjollesha” 54 Tirane \\ ${ }^{2}$ CoPLAN, Institute for Habitat Development, Rruga “Bylis”, nr.12, Autostrada Tirane-Durres, Km 5, Kashar, \\ ${ }^{3} \mathrm{PhD}$ Candidate, Faculty of Architecture and Urban Desing, Rruga “Muhamet Gjollesha” 54 Tirane
}

\begin{abstract}
The city of Tirana has undergone a series of changes in it's urban tissue in the last century. This was due to a paradigmatic shift between different political rules, main historical events, culture and economic stability, etc. Since the establishment of the city as a capital in 1920, the urban blocks, and especially the arrangement of spaces inside this block, have been ever-changing. This study explores some of the characteristics of the urban block between 1920 and 1960, with focus on the "50 vjetori" complex.
\end{abstract}

Keywords: urban block, urban development, built and void, urban transformation, space between buildings

\section{Introduction}

Tirana, the capital that changes every day. Its history development from the creation up to nowadays shows that it has undergone radical transformations not only in socioeconomic terms but also in urban terms. From the study of existing topographical stages and regulatory plans of the 1920 - 1960 period, this research explores the development conditions and the regulatory plans that affected the shape of Tirana's building blocks, from the Austro - Hungarian occupation, through the period of King Zog regime and the Italian occupation, until the first period of the communist regime, in the ,1960-s.

This research is divided in 2 main parts:

The first part analyses the existing situation of Tirana since its establishment period as a capital city, through the Italian occupation, by studying the evolvement of the regulatory plans, in terms of principles and normativity, and the way these plans affected the existing urban tissue.

The second part explores the changes in design ang planning principles after the Italian occupation, until the $1906^{\mathrm{ec}} \mathrm{s}$, reflected in Regulatory Plans and in real interventions, with focus on the " 50 Vjetori"complex

When you submit your paper print it in two-column format, including figures and tables [1]. In addition, designate one author as the "corresponding author". This is the author to whom proofs of the paper will be sent. Proofs are sent to the corresponding author only [2].

\subsection{Research Aim and Objectives}

The main aim of this research is to analyze the evolvement of the urban blocks and the space between the buildings in Tirana in the period 1920-1960, which coincides with the establishment of a series of political rules, from republic, to kingdom, fascist republic, communist monopartiac republic, etc. The following are some of the objectives of this research:
- Understanding which were the elements constituting an urban area in the period 1920 to early 1960s.

- Identifying the Regulatory Plans drafted for the city of Tirana in the period 1920-1960 and analyzing their impact on the existing urban tissue.

- Understanding how the development standards and normatives changed with time and how this affected the residential blocks.

- Revising how the standards of the time were applied in the case of "50 vjetori" complex and how this influenced the layout and livelihood of the area.

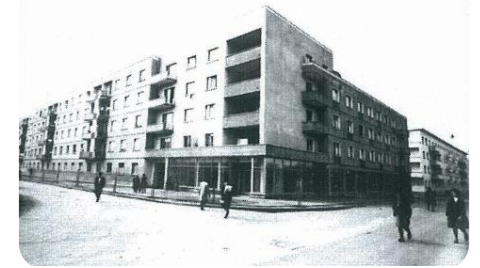

Figure 1: View from “Myslym Shyri” Street

\subsection{Research questions}

1) Which are the main periods of political change that shaped the city tissue and the way planning and design was carried out, in the period 1920-1960?

2) What standards were used in the various regulatory plans that were drafted for the city?

3) How were these standards applied in the "50 vjetori" neighborhood, and how did this influence the livelihood and livability of the area?

\section{The residential blocks in Tirana during the Italian Period}

2.1 Analysis of existing state and regulatory plans of Tirana, from establishment as a capital city, until the Austro - Hungarian occupation.

From an inhabited center, Tirana began receiving the physionomy of an Oriental City with the construction of 


\section{International Journal of Science and Research (IJSR) \\ ISSN (Online): 2319-7064}

Index Copernicus Value (2013): 6.14 | Impact Factor (2014): 5.611

buildings, mosques, shrines, furnaces and bathing in 1614 by Sulejman Pasha Bargjini. Tirana's Position is in the heart of the country, at the junction of commercial arteries linking north to south and east to west. This resulted in the development of a radial road system. This road system creates the possibility of expanding the city by developing later the ring road.

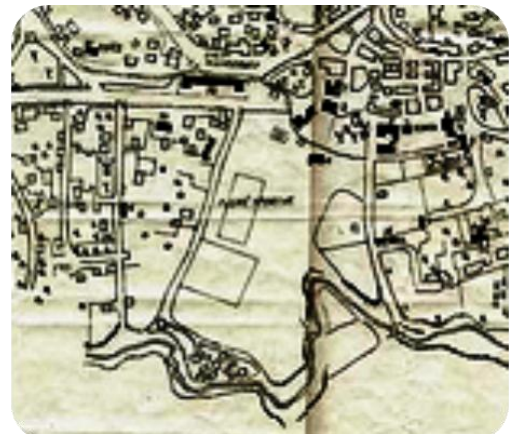

Figure 2: Topographic situation (April 1917),[1]

The first topography study (Fig. 2) carried by the Austro Hungarians in 1917 clearly shows that the development of the city has an disorganized and irregular shape. Roads pass through the town center (the market) but do not have a regular geometric shape. Downtown are the main buildings, like: The State Command, The Bakery, The State Gendarmerie, The Post-Office, The Prefecture, etc. Apartments have mainly an altitude of 1 and 2 storeys, positioned along the roads and alleys wandering without any urban rule. The 304 ha area of the city is composed mainly of buildings. $98 \%$ of the flats are mainly in the northern and eastern side. There is a lack of shared surfaces such as green gardens, parks and recreational areas. There is only one sport field. The neighborhood streets are often discontinous. The space between dwellings contained no particular order. The apartmens were located in different positions without any rule regarding property lines.

In 1921 the area of the city grows to 350 ha (Figure 3), Tirana has the same radial road system while buildings tend to develop to the southwest side of the city, mostly private residences with altitude up to 2 storeys. Tirana's typical medieval dwellings were characterized by the organization of rooms around a common environment that had the height of two floors and was called the fire house. Aristocracy apartments usually were made with high walls built of adobe and inside their space a garden with trees and flowers was introduced. Private dwellings were organized on neighborhoods but without urban rules. This because of the feudal land management and the lack of specialists in the State Administration. The space between the apartments did not follow any urban condition. It continues to feel the lack of common recreational areas. There were several small squares, in front of mosques, where the prayer ritual was conducted. Located in the center of Tirana, near the bazaar, were the places which served for selling goods. On the south side of Tirana lays the irregularly flowing Lana river.

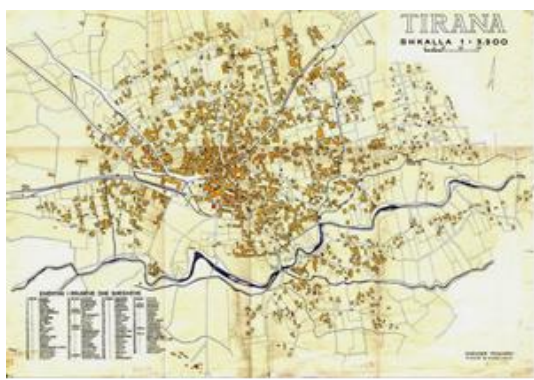

Figure 3: Existing condition of Tirana (March 1921),[1]

The first Regulatory Plan of 1923 was drafted (Fig.4) by an Austrian architect and engineer. The Plan contained a quadratic road system and later was followed by the partial plans of the Austrian architect Wolfgang Köhler but agreeing the main Regulatory Plan. This plan preserves some directions of the existing streets and roads and it consists mainly of a radial road structure typology.

During the Austro-Hungarian occupation, the Regulatory plans and partial studies of 1926, which followed, brought some improvements in the street network. Extensions of several roads were made, like: "Kavaja Street", "Dibra Street", "Street of the Barricades", "Durrës Street" etc.

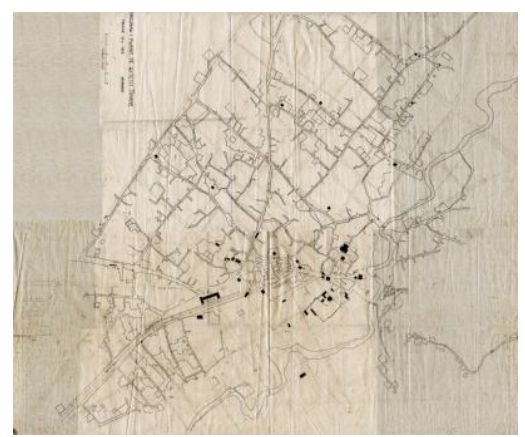

Figure 4: The first regulatory plan in 1923.,[1]
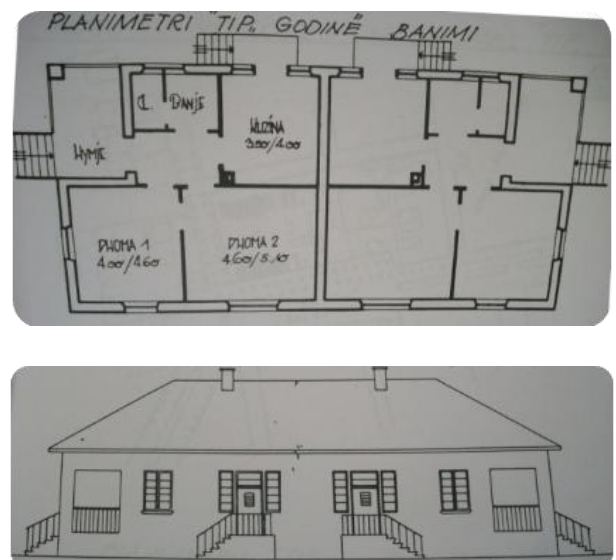

Figure 5: Project of a typical household. Ark. Kohler 1929

\subsection{Analysis of regulatory plans and existing conditions in the period of King Zog regime.}

In 1924, with the election of Ahmet Zogu as prime minister of Albania, the regulatory plans that were developed at his request, contained a tendency for the development of a Western-oriented culture. Kohler Wofgang Austrian architect designed typology of 1 storey roofed houses, which had an organization that did not fit Tiranaes original dwellings.

\section{Volume 4 Issue 12, December 2015}


These flats were built in the early $1929^{\circ}$ s. Following the regulatory plans of the Austrians, the Italian architect Armando Brasini and later the urbanist/architect, Florestano di Fausto drafted regulatory plans that transformed drastically the urban structure of Tirana. (Fig.6). The 1929 Regulatory Plan does not take into account the existing roads of the city.

This plan defines the urbanization limits of the town and encourages the separation of residential areas from the administrative ones. The plan provides Lana river's systematization and the separation of residential areas by a regular quadratic system. The city was planned to extend in the eastern side with a quadratic road system. The population in this period was around 30000 inhabitants in an area of 12 $\mathrm{km} 2$. There was an improvement of the existing road system. The north-south axis opened as the main boulevard, which would settle administrative facilities. This quadratic block design transformed the perception of the urban residential areas and included all inhabitants, not just the city's elites. The 1928 Regulatory Plan designed by Austrian architect Wolfgang Kölher can be considered innovative, in the way it deals with the vast unoccupied area in the western part of the city, now called "the new Tirana". He proposed a concentric ring road system dividing it into regular plots with $1200-$ $1500 \mathrm{~m} 2$ areas. This opened up the space for green areas and diverse gardens. The following adjustment plans of 1929, 1934 and 1939 created the possibility of constructing private villas with an architecture design that would resist in time.

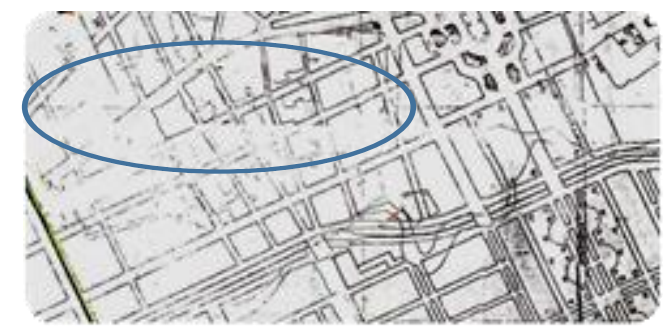

Figure 6: The 1929 Regulatory Plan.

\subsection{Analysis of regulatory plans and existing conditions in the period of the invasion of fascist Italy.}

The Invasion of Albania from fascist Italy, had a major impact on architecture and the urban development of the country. A long-term regulatory plan was designed to cope with the population growing up to 100000 inhabitants. The architects Gerardio Bosio, Ferdinando Poggi and Ivi Lambertini designed another plaza, besides "Skanderbeg Square", at the foot of the southern boulevard, today called "Mother Teresa Square". In 1937 Tirana occupied an area of 607 ha while in 1944 it amounted to 720 ha. The master plan drawn up by the group of architects and planners paid special attention to the greenery in residential areas. It was predicted that the expansion of Tirana would become on its northern side near the Tirana river (Fig. 5). The plan gave importance to the regulation of Lana river, the location of hospital and industrial areas and other structures, that laid the foundations of a modern capital and helped its growth and transformation rapidly.

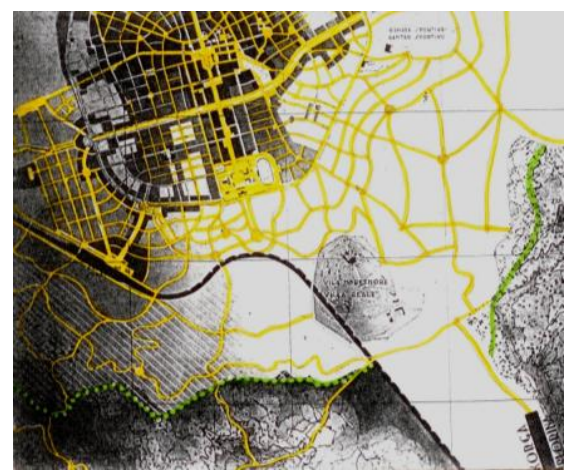

Figure 7: Excerpt of the 1942 Master plan.,[2]

This masterplan was supposed to be completed in stages and it could be without hesitation the first normative regulation of urban design in Albania. The plan clearly defined all types of roads, the pavement widths, types of lighting and their heights, conditions of the urban block, the heights of buildings with or without storeys, etc. Residential areas are divided in different construction intensities. This plan preserved the radial system regulated by the junction of the ring systems, which created enhanced space provided for an increased traffic. During this period the regulatory plans have been amended several times and are accompanied by different partial studies. This plan, along with the road system was never implemented. The most important moving vehicles became the chariot, phaeton, engines and a small number of automobiles. Tirana in 1944 occupied an area of 720 ha.
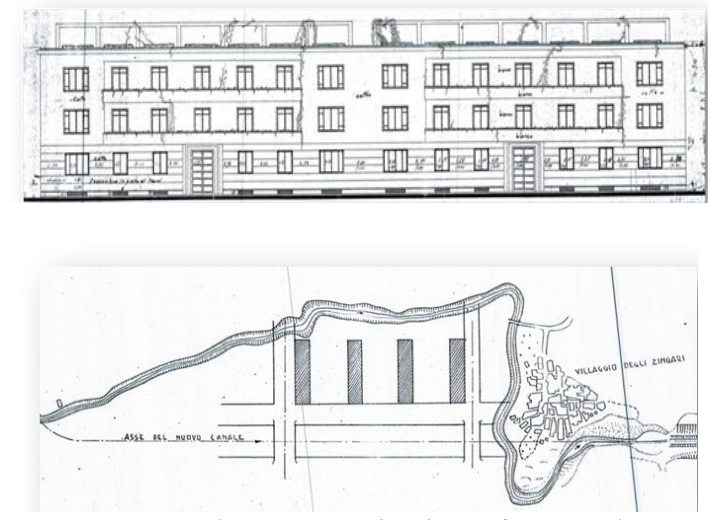

Figure 8: The systematisation of Lana River

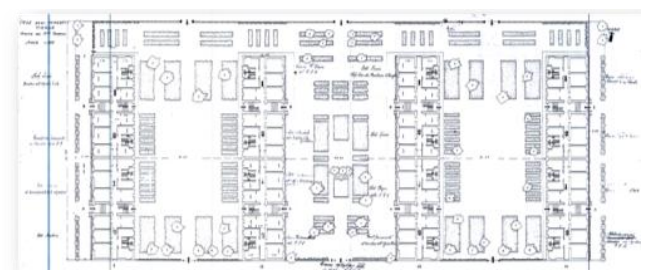

Figure 9: The site-plan and adjustment of space between housing

The first residential block was composed by:

- Green Parks

- Parking

- Recreational inner courtyard

The urban blocks were generally placed in a north-south orientation, had spacious ventilated areas, sunlit from the 


\section{International Journal of Science and Research (IJSR) \\ ISSN (Online): 2319-7064}

Index Copernicus Value (2013): 6.14 | Impact Factor (2014): 5.611

south. These blocks contained contemporary architectural elements, had a height of $12 \mathrm{~m}$ and $33 \mathrm{~m}$ distance from each other. In 1940 Italian architect Piero Bartolini designed a typology of 3 floor apartments with basement, which were used as typical apartment design. These were repeatedly implemented in some areas of Tirana, creating different planning compositions and a new architectural and urban style of the residential blocks.

\section{The Residential Blocks in Tirana after the Italian Occupation}

\subsection{Analysis of urban development after liberation and the plan of 1957}

The Regulatory Plan of 1957 was drafted following the existing road system. The city was predicted to expand its limits to todayes "Ring Road". (Figure 8). The regulation of Lana river and the two boulevards on both sides were taken into account in this plan. Their implementation was completed in 1965. The 1957 regulatory plan provided individual flats of 2 storeys and collective dwellings of 4 storeys, with linear arrangement along the main roads, creating open and closed blocks with collective dwellings and standard apartment typologies. The plan was designed by Albanian architects and helped prevent any unplanned construction. Tirana in 1945 had a population of 60,000 inhabitants, in 1955 it increased to 110,000 inhabitants, and in 1960 up to 136,500 inhabitants. The new 1957 plan envisioned an expansion and extension of the town towards Dajtit mountain, on the eastern side. The road system was expected to be radial-ring again, giving importance to the north-south axis boulevard. The Regulatory plan preserved the outer ring, designed in the 1942 plan.

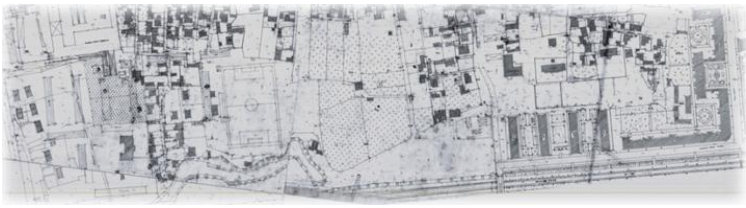

Figure 10: Existing condition of Tirana 1957

The existing residential situation in 1959-62 reflects mostly individual apartments located along streets, positioned in the rear end of the respective yards. The urban blocks didn't contain any playgrounds, squares, parks or service facilities. Moreover, the location of villas didn't follow any regulated pattern and usually the distances between them were not respected. Most of private courtyards were green, with colorful flowers, and fruit trees, and constituted the space of social gatherings and outdoor activities for the inhabitants of the block.

Creating large spaces between the housing and the position of kindergardens and yards through blocks and the placement of 8 - year schools across residential complexes enabled the creation of sports fields, green spaces and recreational spaces between buildings. Traffic was realized by bus service, and private cars were almost nonexistent. Street movement consisted mostly of state vehicles and bicycles.

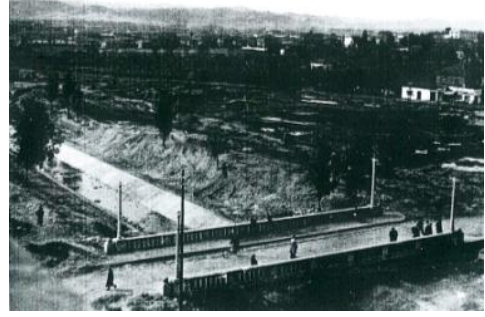

Figure 11: Tirana, 1959, the site where now lays the "50 vjetori" complex, [2]

\subsection{Case study: The "50 vjetori" complex}

This section explores some of the characteristics of the design principles of the time, specified in the "50 vjetori" complex. This complex is situated along the Lana river, and covers an area of approximately 24 ha.

During the $1960^{\circ} \mathrm{s}$, the inner space between dwellings was treated as a resting place of entertainment, which provided the architectural spatial connection for the dwellings of 4 and 5 storeys of height. This space contained all the elements that constitute a successful urban block/complex, such as: a park, service facilities, paths, playground for children and seniors, internal roads and sidewalks. Only parking spaces were lacking, because residents didn't have any private vehicles at the time.

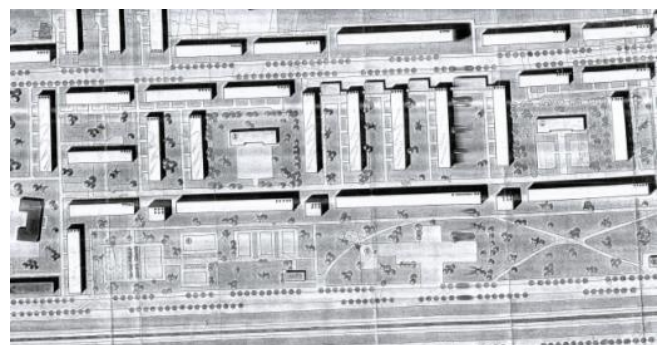

Figure 12: One of the design scenarios of the " 50 vjetori" complex, 1960,[1]

Many design scenarios were proposed for the "50 vjetori" complex. The following is a list of some design principles applied in the case of this complex:

- The main form of organization was the block housing and residential complex, with Russian style dwelling typology, designed by Albanian architects and built by state enterprises.

- These solutions provided housing, recreational areas, greenery, service roads for the residents and the visitors of the complex.

- The residential block had flats arranged on a distance between them of no less than $1.5 x$ height of the building.

- The complex covered an area of 24ha, with a number of approximately 7400 residents on a 12.2 ha residential area. Gross density of the residential area was $308 \mathrm{ba} / \mathrm{ha}$.

- Recreational squares between collective housing except the relaxing function created the possibility of recognition, friendship, self-control and management of each resident ,life.

- The linear establishment of buildings in the north side of the complex, protected the playground areas from wind, street noise and oriented them on the southern side. 


\section{International Journal of Science and Research (IJSR) \\ ISSN (Online): 2319-7064}

Index Copernicus Value (2013): 6.14 | Impact Factor (2014): 5.611

In overall, this complex followed a "human-scale" -friendly layout, with normative that aimed at creating a healthy living, good social surroundings and a high regard for environmental principles, openness and accessibility. These principles are highly valued even today, by post-modernist theories, where an emphasis is put on linking the indoors with the outdoor space, because "A good internal space should not be blocked off by bland walls. It should be visible from the street; and its surroundings should be highly visible from it",[6]

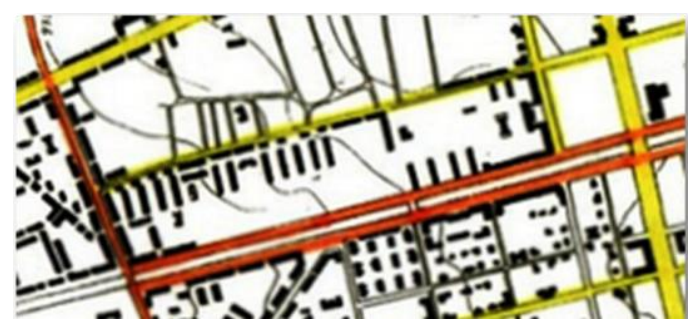

Figure 11: The urban situation of the "50 vjetori" complex, 1960-1965, [2]

\section{The Methodology}

This is a descriptive and analytical type of research, which is based on analyzing and interpreting data from the regulatory plans of the period 1920-1960 in Tirana, as well as other literature sources and data collection methods.

This research is of an inductive type, since it begins by drawing general conclusions, based on desk surveys, and confirms these conclusions by focusing into a small area ("50 vjetori" complex), and analyzing in detail aspects of its development in time.

Data collection is carried out in two ways: referring to the Central Technical Archive of Construction, which provided the database for the analysis of the previous city plans and masterplans, and through a questionnaire, conducted in the "50 vjetori" neighborhood, which tries to give some insight on the quality of living and the memories that the inhabitants share for the past of the complex. Other resources include foreign literature on urban space and urban blocks, other institutions and the library.

The data analysis was realised through the use of several indicators, which were observed for the plans under study. Some of these include:

- The presence of parks

- The structure of inner roads

- The presence of sidewalks

- The distribution of service facilities

- The alignment of the building blocks

- The altitude

- The architectural elements of the buildings, etc.

This data was further analysed, in terms of compatibility with the reality (whether the principles proposed by the plans were implemented or not) and in terms of normativity (whether there were specific quantitative standards that regulated this or not).

\section{Conclusions}

This study contributes to the perception of space between the housing and the revitalization of residential spaces.

In $1920^{\circ} \mathrm{s}$, the city structure was organic, without an organized urban tissue and a predominating oriental social and urban culture.

The regulated space organization between buildings starts to take effect in the first regulatory plan of 1942, designed by Italian architects

In 1950 there were many unused spaces, making the city not livable and unattractive.

The space between buildings after $1960^{\circ} \mathrm{s}$, created optimal conditions for solar lighting and house ventilation. The organization of life was based on activities controlled and surveyed by the system.

The residents living in the "50-vjetori" complex still have nostalgia for the greenery and the illuminated sunny areas, full of children playing in it. Today the space is mostly transformed losing its originality.

In the early $1950 \mathrm{~s}$, the site where the complex exists today was not exploited, but it was overseen by regulatory plans, to have squared-shaped blocks with a road system and dwellings positioned circumferentially.

The complex"s indoor spaces are beautifully combined with the linear boulevards along the Lana river and are very close to the city center. Spaces between the complex"s buildings particularly provide a welcoming and friendly atmosphere for the dwellings.

The space, or yard as popularly called, has been attractive and encouraging for as long as people were quiet and not surveyed during a break, resting and being entertained inside it.

In the inhabitants' memory, the space between the housing was defined as a public space, recreational and very functional.

\section{References}

[1] Central Technical Archive of Construction Nr 1. 1999 Tirana - Albania

[2] Central Technical Archive of Construction Nr 3. 2000 Tirana - Albania

[3] Panerai, P., et al, Urban Form, "The death and life of the urban block", Architectural Press, 2010

[4] Gehl, J., "Cities for people", Island Press, Washington DC. p 16, 2010

[5] Gehl, J., "Life between buildings", Island Press, Washington DC., , 2006

[6] White, W., "The social life of small urban spaces", (Project for public space) Conservation Foundation,p.,79, 1980.

Volume 4 Issue 12, December 2015 